\title{
Topics, Subjects and Grammatical Change: \\ from Classical to Modern European Portuguese
}

Tópicos, sujeitos e mudança gramatical:

do português clássico ao português europeu moderno

\author{
Silvia Regina de Oliveira Cavalcante \\ Charlotte Galves ${ }^{2}$ \\ Maria Clara Paixão de Sousa ${ }^{3}$
}

\begin{abstract}
This paper presents a diachronic account of the syntax of subjects in Portuguese by comparing three different constructions - active, canonical passives and SE-constructions - relating the change in the position of subjects to the loss of V2. In the V2 grammar, in which the pre-verbal position is associated with fronted elements, and non-fronted subjects remain in post-verbal position, we see the same patterns of word order in SEconstructions as in active and canonical passive sentences; in the (X)SVO grammar, in which the subject is associated with the preverbal position and the fronted elements occupy the left periphery of the clause, active and canonical passives show a significant increase of pre-verbal subjects, whereas SE-constructions remain alike with respect to word order. We interpret this result as evidence for analyzing the internal argument of SE-constructions as a complement rather than a subject.
\end{abstract}

Keywords: position of subject; V2; Portuguese; SE-constructions.

Resumo: Este artigo apresenta uma análise diacrônica para a sintaxe dos sujeitos em português através da comparação de três construções diferentes - ativas, passivas e construções com SE - relacionando a mudança na posição dos sujeitos à perda de V2. Na gramática V2, na qual a posição pré-verbal está associada a elementos topicalizados, e sujeitos não topicalizados permanecem na posição pós-verbal, encontramos os mesmos padrões de ordem nas construções com SE, nas ativas e nas passivas; na gramática (X)SVO, na qual a posição do sujeito está associada a uma posição pré-verbal e os elementos topicalizados ocupam a periferia à esquerda da sentença, as construções ativas e passivas apresentam um aumento significativo no percentual de sujeitos pré-verbais, ao passo que as construções com SE permanecem estáveis com relação à ordem. Interpretamos esse resultado como evidência para analisar o argumento interno das construções com SE como sendo um complemento e não um sujeito.

Palavras-chave: posição do sujeito; V2; Português; construções com SE.

\footnotetext{
${ }^{1}$ PhD degree in Linguistics, University of Campinas. Professor at Federal University of Rio de Janeiro, Brazil. silviare@gmail.com.

2 PhD degree in Portuguese, University of Paris IV (Paris-Sorbonne). Professor at University of Campinas, Brazil. charlotte.mgc@gmail.com.

3 PhD degree in Linguistics, University of Campinas. Professor at University of São Paulo, Brazil. mariaclara.ps@gmail.com.
} 


\section{Introduction}

Portuguese provides an interesting field for comparative/historical syntax, particularly with respect to the syntax of subjects: in Modern European Portuguese (henceforth EP), the general pattern as regards the position of lexical subjects is comparable to the pattern observed in other null-subject Romance languages, with generalized SV and the possibility of VS in Romance inversion (AMBAR, 1992; COSTA, 2004); however, in Portuguese texts written up to the 18th century the immediate pre-verbal position is reserved for pragmatically prominent constituents, regardless of their syntactic status as subjects, complements, or other - in other words, there is evidence of a "V2-like" grammar, which has in common with the Germanic V2 languages the movement of the verb to a high position, in the $C$ layer, and differs from them with respect to the obrigatory movement of a phrase to the preverbal position (cf. RIBEIRO, 1995, for Old Portuguese; TORRES MORAES, 1995; GALVES, 1996; PAIXÃO DE SOUSA, 2004 and GALVES; PAIXÃO DE SOUSA, 2015, for Classical Portuguese).

Recent work has shown that the change to EP SV syntax can be seen in texts written by the generations born in the first half of the 18th century: Galves and Paixão de Sousa (2015) attest that the proportion of postverbal subjects fall from an average of $21 \%-35 \%$ in the 16 th and 17 th centuries to an average of $12 \%-11 \%$ in the 18th and 19th centuries, while the proportion of pre-verbal subjects increases from an average of $18 \%-17 \%$ in the 16th and 17th centuries to an average of $41 \%-34 \%$ in the 18th and 19th centuries (the proportions of null subjects, while varying considerably along this four-century period - $61 \%-48 \%-47 \%-55 \%$ - show no significant tendency for change). The general picture, in short, is that before the 18th century, subjects tend to behave like other arguments as to their order in the clauses, being either pre or post-verbal, and after that point, they start to show a specific behavior - appearing preferably as pre-verbal. This change in the position of subjects has been taken as the reflex of the change from a V2/V-to-C grammar into an SV grammar.

One kind of construction, however, does not follow the general pattern of change attested for the subject position, as we show in this paper: the so-called "passive" SE-construction. The discussion around the grammatical nature of this construction is of special interest, since it involves the notion of "subject", more specifically the question of whether it is associated with a specific position in the sentence or with the triggering of agreement with the verb, as we try to summarize here. The diachronic data we bring, contrasting the evolution of those constructions with the evolution of general VS and SV orders in Portuguese, may add important elements to this debate.

The so-called "passive" SE-constructions are constructions with transitive verbs that have an internal argument that agrees with the verb, as shown in example ${ }^{4}$ (01a) below. The agent, external argument, is interpreted as generic or indefinite because of the features [+human, -definite] that SE carries. Many studies have discussed the status of SE in these constructions, both in the Government and Binding and in the Minimalist framework, and the great majority of them claim that SE is an accusative-passive clitic and the internal argument is analyzed as the subject (see references below). This kind of analysis, thus, associates "subject" with agreement patterns with the verb. In the history of Portuguese, however, another change is attested involving these constructions: the constructions that do not exhibit agreement between the internal argument and the verb have been analyzed as impersonal-SE constructions, in which the internal argument is the object, as seen in (01b). Naro (1976) claims that the appearance of the impersonal construction with SE in Portuguese is due to a reanalysis from passive SE-constructions and this change came to completion by the $16^{\text {th }}$ century: the subject of this passive construction is reanalyzed as an object, and the external argument is interpreted as arbitrary because of the clitic SE. The author claims that the evidence for this reanalysis relies on agrammaticality of sentences with a PP external argument, as shown by the contrast in (02):

(01) a. Vendem-se essas casas.

Sell-PRS.3PL=SE these house-PL

"these houses are being sold"

b. Vende-se essas casas.

Sell-PRS.3SG=SE these house-PL

"someone sells houses"

${ }^{4}$ We use the Leipzig Glossing Rules (www.eva.mpg.de/lingua/) as a convention for the formatting of glosses in the examples. 
(02) a. Como Josep se conheceu pelos irmãaos. (14 th century - NARO, 1976, p. 789)

how Josep SE=know-PST.3SG by-the-PL brother-PL

'How Josep was recognized by his brothers'

b. *doam-se livros pela bibliotecária

donate-PRS.3PL=SE book-PL by-the librarian

"books are donated by the librarian"

c. doam-se livros

donate-PRS.3PL=SE book-PL

"they donate books" / "books are being donated"

As we mentioned above, the puzzle with these constructions involves the notion of "subject". On the one side, it has been widely claimed that when the internal argument DP of SE-constructions triggers agreement with the transitive verb, it should be analyzed as a postposed subject associated with an empty category in subject position or a preverbal subject (see a.o. MANZINI, 1986; CINQUE, 1988; DOBROVIE-SORIN, 1998; CYRINO, 2007). Therefore, the different patterns of agreement seen in the contrast in (1) would be associated with two different structures: in (1a) the DP "essas casas" is analyzed as a postverbal subject; in (1b) the DP "essas casas" is analyzed as an object. The problem with these analyses is that they rely on the assumption that these DPs are always subjects, since they agree with the verb, regardless of the behavior of subjects in Romance, specifically in Portuguese: in Romance Null Subject Languages the subject position is preferably preverbal and there is a significant rate of null subjects. The so-called subject of these SE-constructions, by contrast, is preferably postverbal. In this paper, we intend to answer the following questions concerning SE-constructions and the position of subjects in the history of Portuguese:

1. How do SE-constructions behave with respect to the position of the argument traditionally analyzed as a subject, when compared to constructions that involve non-controversial subjects and subject positions?

\section{What is the evolution of these constructions regarding the attested change in subject position?}

This paper presents a diachronic account of the syntax of subjects in Portuguese by comparing three different constructions (active, canonical passives and SE-constructions) relating these two phenomena - change in the position of subjects and in SE-constructions - to one single parametric change: the loss of V2/V-to-C. We will show that the change in subject position in the history of Portuguese has divergent consequences: in the old grammar, in which the preverbal position is associated with fronted elements, and non-topicalized subjects remain in post-verbal position, we see the same patterns of word order in SE-constructions as in active and canonical passive sentences; in the (X)SVO grammar, in which the subject is associated with the preverbal position and the topicalized elements occupy the left periphery of the clause, active and canonical passives show a significant increase of pre-verbal subjects, whereas SE-constructions remain alike with respect to word order.

In order to show this contrast, we bring an analysis of the evolution of XVS to SV(X) in Modern European Portuguese based on a corpus of 11 syntactically annotated texts written by Portuguese authors born between 1510 and 1836 drawn from the Tycho Brahe Parsed Corpus of Historical Portuguese (henceforth TBC). By contrasting active sentences, canonical passive and SE-constructions, we reveal how the behavior of the preposed internal arguments of canonical passives patterns with the behavior of the external arguments of active clauses, differently from the behavior of internal arguments of SE-constructions. This comparative study leads to the following prediction, based on the available data from active sentences: (a) if preposed constituents (either subjects or objects) are topicalized in 16th-17th century Portuguese because of their prominent informational status; (b) if, along the time, the frequency of VS falls, giving rise to generalized SV; and (c) if we assume that the change does not affect the frequency of topic prominent elements - then, word order will present frequency alterations only in true SV sentences, not in sentences with prominent topics which are not subjects.

If these constructions involve movement of the DP to the subject position, when preposed, and if the DP is a postposed subject, then we would expect that they present the same statistical behavior as the other two constructions. However, as we show, this is not what happens. The observed change, therefore, supports Raposo \& 
Uriagereka's (1996) proposal, by which the preposed argument goes to the specifier of an FP position, at the left periphery of the sentence, and SE goes to the subject position ${ }^{5}$.

Summarizing, we will present a comparative analysis of the position of arguments, often treated as subjects, in order to make the following points:

(1) the arguments in SE-constructions are not subjects, but topics, associated with a complement position;

(2) the arguments of active and passive constructions that trigger agreement with the verb are subjects;

(3) the change in V2 in Portuguese had reflexes in the position of subjects, but not of complements.

The paper is organized as follows. Section 1 presents evidence that Classical Portuguese is a V2 language, of the kind outlined by Cruschina and Sitaridou's proposal for V2 in Old Romance. In section 2, we present the quantitative analysis based on data extracted from the TBC. Finally, in section 3, we analyze the frequency patterns of preverbal elements and their status in the two grammars - Classical Portuguese (henceforthe CIP) and Modern European Portuguese (henceforth EP) - by scrutinizing preverbal subjects and topicalized XPs. We then relate these results to Raposo and Uriagereka's analysis of SE-constructions.

\title{
1. Classical Portuguese is a V2 language
}

CIP (the grammar represented in $16^{\text {th }}$ and $17^{\text {th }}$ century Portuguese texts) has been analyzed as a V2 grammar in several studies (cf. TORRES MORAES, 1995; GALVES, 1996; PAIXÃO DE SOUSA, 2004; GALVES; BRITTO; PAIXÃO DE SOUSA, 2005; GIBRAIL, 2010; GALVES; PAIXÃO DE SOUSA, 2015; GALVES; GIBRAIL forthcoming). In order to understand this claim - which we sustain in the present paper - a more specific approach to "V2" becomes necessary. In Germanic languages, as it has been widely discussed, V2 is considered to be a structural requirement of the Sentence; in Romance languages, however, the V2 effect should be analyzed in a different light, considering that such languages present a wider variety of non-V2 orders. Cruschina and Sitaridou (2009) claim that Romance V2 must be considered as "the reflex/result of fronting or dislocation processes". This would mean, in short, that there are two different kinds of "V2", which would differentiate Romance from Germanic languages: in Germanic V2 languages, the verb must move to $C$ because of a structural requirement; in Romance V2 languages, the verb bears some relevant discourse feature and moves to the head of the corresponding functional projection.

The main advantage of this analysis is that, besides V2 orders, it explains patterns of V1 and V3 word orders in Romance':

\begin{abstract}
"The traditional V2 analyses suggest that Medieval Romance word orders involve movement of the verb to $C$ and the additional step of fronting some other pragmatically-salient element to the left periphery under either topicalization or focalization. However, such an analysis has recently been questioned (cf. KAISER 2002, FIÉIS 2003, RINKE \& SITARIDOU 2004, SITARIDOU 2006, RINKE 2006, EIDE 2006, FISCHER 2008), because Old Romance also shows structures which are not compatible with a V2 grammar, such as V3 sentences (...) Verb-movement in Old Romance does not derive from of a general structural requirement, but is instead closely related to the syntactic operations associated with the information structure of the sentence. This accounts immediately explains why V2 in many Old Romance varieties (with the possible exception of Old French) is anything but regular and systematic, other orders proving very common." (CRUSCHINA; SITARIDOU, 2009)
\end{abstract}

CIP is well described as a V2 language of the "Romance V2" type suggested by Cruschina and Sitaridou (2009). Although the V2 order is by far the most frequent one in the $16^{\text {th }}$ and $17^{\text {th }}$ century texts, we also find in these texts V1 and V3 sentences, like in the Old Romance varieties discussed by those authors. The examples (03), (04) and (05) below show the different word orders attested in Classical Portuguese: V1, V2 and V3.

\footnotetext{
${ }^{5}$ What we name in this paper as "SE-constructions" are those constructions often analyzed as passive-SE constructions. All the other constructions that involve the clitic SE, such as inherent, ergative or reflexive/reciprocal, are being treated as subject constructions. We decided to separate them in order to show that these "passive" SE-constructions may not be treated as "passive". For more information on these constructions in Portuguese, see Duarte (2003).

${ }^{6}$ Calves and Paixão de Sousa (2015) make a similar proposal about XP movement in ClP but they provide evidence that the verb does move to $C$.
} 
(03) a. Pelejou a armada de Holanda com uma esquadra da armada Real de Castela (Galhegos, b. 1597) Fight-PST.3SG the navy of Holland with the squadron of-the fleet Royal of Castile "The Dutch fleet fought against a squadron of the Royal fleet of Castile"

(04) a. Com a primeira vista destas suas fanfarrices ficamos nós algum tanto embaraçados. (Pinto, b. 1510) With the first sight of these his aloofness become-PST.IPL we some time constrained "with the first sight of his aloofness we became constrained" b. e bastantes armas the=davam os livros pera se=defender, (Sousa, b. 1556) and many-PL weapon-PL 3PL-DAT the book-PL to REFL=defend "and the books gave him many wepons to defend himself" c. e os novos hóspedes consolamos, e animamos (Pinto, b. 1510) and the-PL new-PL guest-PL comfort-PST.1PL and cherish-PST-1PL "and we comforted and cherished the new guests"

(05) a. Quando Deus veiu a juiso, a terra tremeu, (Vieira, b. 1608) When God come-PST.3SG to reckoning, the earth shake-PST.3SG. "When Cod came to reckoning, the Earth shook"

Indeed it has been claimed in Paixão de Sousa (2004), Galves, Britto and Paixão de Sousa (2005), and Galves and Paixão de Sousa (2005), that in CIP the immediate preverbal position is the landing site for topics and foci. Both subjects and complements in Classical Portuguese are fronted due to informational status. Therefore, the statistical behavior of fronted objects, fronted DPs in SE-constructions and fronted subjects are the same in CIP.

EP on the other hand, is well-known and well described as a SV grammar. In this language, fronted objects are also determined by informational status (such as contrastive topic, for instance) - subjects, however, do not depend on informational status to appear in the pre-verbal position. We claim that fronted DPs in SEconstructions should not be considered as subjects - they are, in fact, fronted constituents, following the same requirements as fronted objects (CAVALCANTE; PAIXÃO DE SOUSA, 2009).

The change from Classical to Modern European Portuguese, therefore, can be translated as a change from a V2 grammar into a SV grammar, in which the immediate pre-verbal position becomes a specific landing site for subjects. This has actually been demonstrated with historical data by the authors mentioned above, by Cavalcante, Galves and Paixão de Sousa (2010) and, more recently, Galves and Paixão de Sousa (2015), based on data extracted from the TBC. These authors show that from the $18^{\text {th }}$ century on there is a sharp decrease of XVS orders and an increase in SV orders. This can be seen in Graph 01.

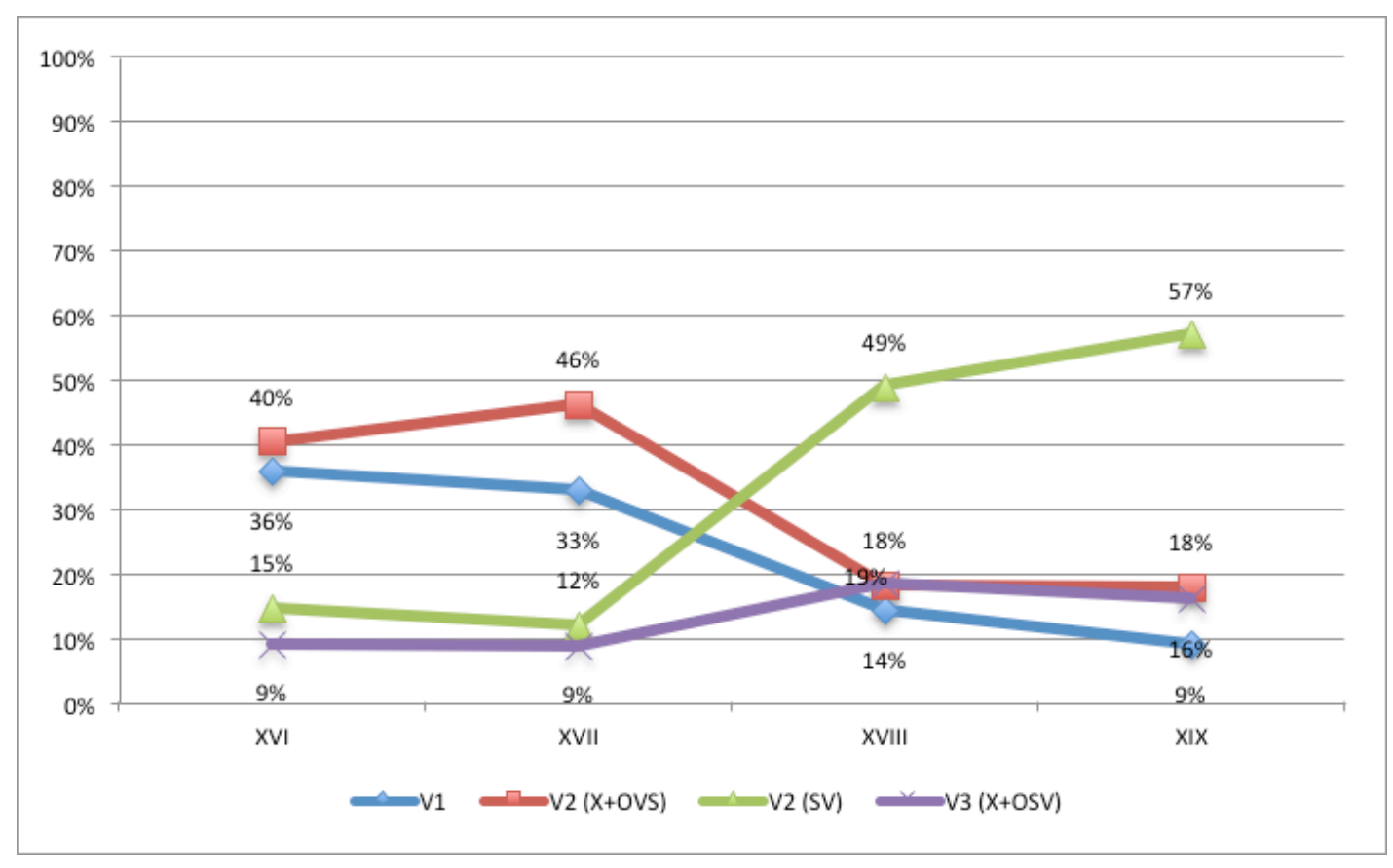

Graph 01. V1, V2 and V3 sentences in the history of Portuguese (CAVALCANTE; GALVES; PAIXÃO DE SOUSA, 2010). 
As we can see from the lines in Graph 01, there is a sharp decrease of postposed subjects in V2 contexts with topicalized objects (red line) and V1 contexts (VS or V+null subject) and a sharp increase of pre-posed subjects in V2 contexts (SV contexts) from the $18^{\text {th }}$ century on and V3 sentences with pre-posed subjects present a slight increase from the $18^{\text {th }}$ century on. These results indicate that there is a correlation between the loss of V2 in the history of Portuguese and the increase of pre-verbal subjects. Galves and Gibrail (forthcoming) describe the same (and still more spectacular) decrease in transitive sentences.

In section 3, we will look at this change focusing on the difference of behavior between SE-constructions on one hand and active and passive sentences on the other. For hypothesis, we believe that if SE-constructions are related to pre-verbal subjects, they will present the same statistical behaviour of ordinary subjects.

\section{Description of the data}

This paper is based on data retrieved from 11 texts that belong to the Tycho Brahe Parsed Corpus of Historical Portuguese (www.tycho.iel.unicamp.br/ tycho) written by authors born between the 16th and 19th centuries ${ }^{7}$. We selected and classified 12.107 tokens of the position of the argument in finite main clauses of active sentences, canonical passives and SE-constructions. It is worth mentioning that SE-constructions only involve the cases traditionally classified as instances of passive-SE; i.e., sentences in which the internal argument agrees with the transitive verb (and which have been analyzed as instances of subject postposing). In this sense, in order to show how the change in subject position does not affect SE-constructions, we make a comparison of three different word order patterns involving these three constructions: null, preposed and postposed arguments, illustrated below. In (06) we show the contrast of null arguments of active, passives and SE-constructions:

(06) a. e pro fugiram manhosamente para onde estava a galé, com determinação de se=fazerem nela fortes" (Pinto, born 1510)

and pro escape-PST.3PL slyly to where rest-PST.3SC the galleon, with determination to REFL=make in-it strong.

"and they slyly escaped to where the galleon was, determined to make themselves strong in it"

b. [O Padre António Vieira] Com o mesmo aplauso, e assombro pro foi ouvido em outras muitas ocasiões, e lugares, enquanto não chegou o tempo de dar à vela para o seu querido Maranhão. (Barros, born 1675)

[Father António Vieira] with the same acclamation, and fear pro was-3SC listened in many other occasions...

c. É acção bárbara, porém é verdadeira e pro foi executada por um monarca. (Cavaleiro, born 1702)

pro is barbarian action, although pro is true and pro was executed by a monarch

d. por isso os votos, que se fazem com violência, sempre se fazem com lágrimas, e também por isso raras vezes pro se=cumprem; porque o coração, e a vontade não prometeram nada; (Aires, born 1705)

thus the vows, that $\mathrm{SE}=$ make-PRS.3PL with violence, always $\mathrm{SE}=$ make-PRS.3Pl with tears, and also because of that rarely SE-keep-PRS.3PL, because heart and will haven't promised anything.

e. As janelas fizeram=se para alumiar as casas, e arejá=las, pro não se=fizeram para ter senhoras penduradas. (Ortigão, born 1836)

the windows make-PST.3PL=SE to lighten the houses and air=DAT-3PL, NEG SE=make-PST.3PL to have hanging ladies.

The examples in (07) illustrate the preverbal arguments of active, passives and SE-constructions.

\footnotetext{
7 The texts are available at < http://www.tycho.iel.unicamp.br/ tycho>: Fernão Mendes Pinto (1510-1583), Perigrinação; 47,580 words; Luis de Sousa (1556-1632), A vida de Frei Bertolameu dos Mártires - 53,928 words; Manuel de Galhegos (1597-1666) Gazeta - 28,839 words; Antonio Vieira (1608-1697), Sermons, 53,855 words; Maria do Céu (1658-1753), Rellaçaõ da Vida e Morte da Serva de Deos a Venerável Madre Elenna da Crus, 27,410 words; André de Barros (1675-1754), A vida do Padre Antonio Vieira, 52,055 words; Cavaleiro de Oliveira (1702-1783), Cartas; 51,234 words; Matias Aires (1705-1763), Reflexões sobre a vaidade dos homens, 56,479 words; Marquesa de Alorna (1750-1839), Letters, 49,512 words; Marques de Fronteira e Alorna (1802-1881) Memórias do Marquês de Fronteira e Alorna, 54,588 words; Ramalho Ortigão (1836-1915), Cartas a Emília, 32,441 words.
} 
(07) a. "Uns Índios deixavam as aldeias", (Barros, b. 1675) Some indians left-PST.3PL the villages

b. "Os mesmos sagrados Canones respondem à minha pergunta". (Vieira, b. 1608)

The same sacred canons answer-PRS.3PL to my question

c. O nosso hóspede foi muito bem recebido. (Marques de Alorna, b. 1802)

Our guest be-PST.3SG very well received.

d. Um clérigo capelão, e intérprete do embaixador de Veneza, foi preso... (Galhegos, b. 1587)

A clergy chaplain, ambassador's of Venice interpreter, be-PST.3SG arrested

e. "As janelas fizeram=se para alumiar as casas, e arejá-las" (Ortigão, b. 1836)

The windows make-PST.3PL=SE to lighten the houses and to air-them.

"The windows were made to lighten and air the houses"

f. "e o mesmo se fazia dos sobejos da mesa dos hóspedes" (Sousa, b. 1557)

and the same SE made=3PS from the leftovers of the guests' table

Finally, in (08) we illustrate the postverbal position of the arguments in these three constructions ${ }^{8}$. It is worth mentioning that we are considering for analysis various types of VS order, be it V1, as seen in (08a) and (08b) or V2 with a preposed element other than the subject as in (08c)-(08e).

(08) a. "Contam as histórias deste Reino que el-Rei Dom Afonso Anriques, primeiro e mais antigo dos que nele contamos, despois de ter ganhado aos mouros a mor parte das terras de Portugal, de que eram senhores, quando herdou o Reino, havia por afronta sua possuírem Lisboa, que só por si era outro reino;" (Sousa, born 1557)

Tell-PRS.3PL the stories of this Reign that el-Rei Dom Afonso Henriques...

b. "Vem Christo a julgar todos os dias; porque no ponto em que cada um expira, logo o vem julgar, e julga, não outrem, senão o mesmo Christo". (Vieira, born 1608)

Come-PRS.3SG Christ to judge every day ...

c. "N'este sentido diz o Ecclesiastico pelas mesmas palavras do nosso texto: Generatio proterit, generatio advenit" (Vieira, born 1608)

In this sense say-PRS.3SC the Ecclesiastes for the same words of our text...

d. "Para justificar êste excesso, alegam as beatas a bondade divina, que não repara como nós nas cousas exteriores"; (Aires, born 1705)

To justify this excess, claim-PRS.3PL the nuns the divine goodness, that doesn't pay attention to the exterior things.

e. Foram as vésperas celebradas com toda a solenidade possível polo bispo e cabido. (Sousa, b. 1547)

Be-PST.3PL the Vespers celebrated with all the possible solemnity by the bishop and cleric

f. Em Grijó foi gravemente ferido um velho fidalgo de setenta anos... (Marquês de Alorna, b. 1806)

In Grijó be-PST.3SG severely wounded an old nobleman of 60 years old

g. e na defesa delas foram mortas da nossa parte onze pessoas... (Pinto, b. 1510)

and in their defense BE-PST.3PL killed of our part eleven people

h. Por estes jogos, mais que pelo curso do sol, se=contavam e distinguiam os annos. (Vieira, born 1608)

By these games, more than by the sun course, $\mathrm{SE}=$ count-PST.3PL and distinguish-PST.3PL the years.

i. Conhecem-se os verdadeiros Prophetas pelos olhos, porque o vêr é o fundamento do prophetisar. (Vieira, b. 1608)

Know-PRS.3PL=SE the real prophets by their eyes, because seeing is the base of prophesying

In the next section, we present the comparative evolution of null, preposed and postposed arguments in the three constructions exemplified above. We examine the evolution of null along with preposed and postposed arguments bearing in mind that both CIP and EP are null subject grammars; therefore, the rate of null subjects will supposedly remain stable. We then present the distribution of preverbal and postverbal arguments along the time in these three constructions.

\footnotetext{
${ }^{8}$ In passive constructions there are two possible positions for the post-verbal subject: either after the inflected auxiliary verb, either after the past participle, as shown in examples (8e) and (8f) respectively. This aspect is much properly treated when one discusses the types of inversion (Germanic or Romanic) that these data may raise. As we are interested in aspects related to argument fronting in Classical and European Portuguese, we have decided to present both word orders as post posed subjects, as opposed to pre-verbal (or fronted) subjects.
} 


\section{The evolution of word order from Classical to European Portuguese}

In this section we show the effect of the loss of $\mathrm{V} 2$ in Portuguese through the behavior of the position of the arguments and its relative frequency along the centuries. First and foremost, we will show the comparative behavior of null, postverbal and preverbal arguments along the centuries, then we will discuss in more detail the preverbal elements.

Let us first consider Graph 02 with the compared evolution of arguments (preverbal, postverbal or null) in $\mathrm{SE}$, active and passive constructions.

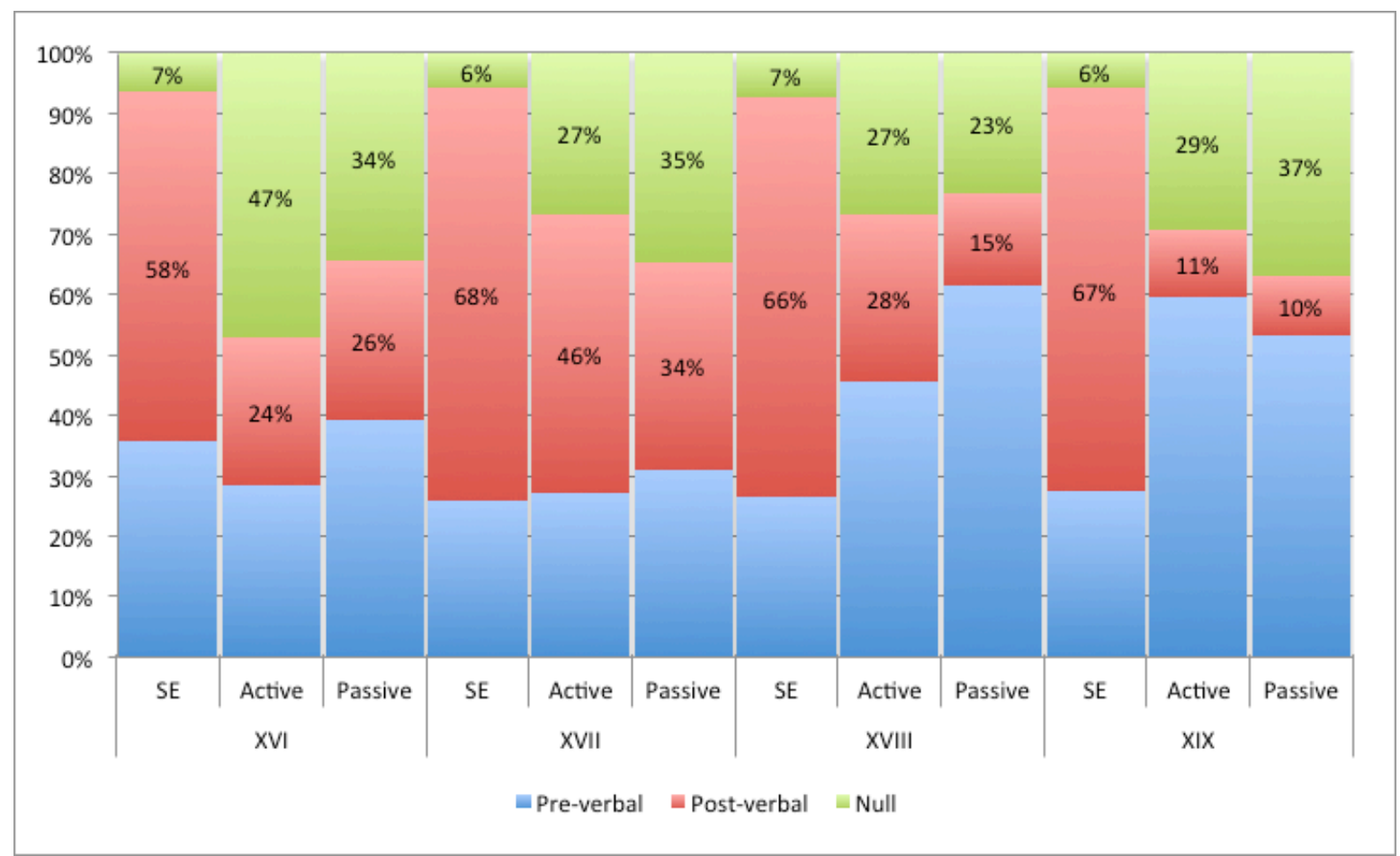

Graph 02. Compared evolution of argumetns (preverbal, postverbal and null) in active, passive and SE-constructions by century.

Let us first consider null arguments: the rates of null subjects slightly vary along the time in active and passives, between $50 \%$ and $60 \%$ in active sentences and $30 \%$ and $40 \%$ in passives. The rates of null arguments in SE-constructions also vary, but they are not higher than $15 \%$ in the last period. The comparison of the rate of these null arguments in the three constructions was based on the assumption that given that both Classical and Modern European Portuguese are null subject grammars, we should not expect any change concerning the rates of null arguments. This prediction is confirmed. The comparison of the rates of null subjects with the rates of null arguments in SE-construction, however, may lead us to the first hint that the DPs in SE-constructions, even triggering agreement with the verb, may not behave as subjects.

Let us now consider the behavior of preposed arguments along the time, as shown with the blue columns. We observe that the rates of preposed arguments in active and SE-constructions are rather equivalent during the $16^{\text {th }}$ and $17^{\text {th }}$ centuries, with some variation concerning the rates of preposed subjects in passive constructions in the $16^{\text {th }}$ century. From the $18^{\text {th }}$ century on, in contrast, subjects of active and passive sentences present a substantially higher rate of pre-verbal order than the argument of SE-constructions.

This result is confirmed and reinforced when we see the evolution of postverbal arguments in the three different constructions. The rate of postverbal arguments in active and passive constructions decreases from the $18^{\text {th }}$ century on. By contrast, the DPs of SE-constructions continue to be highly preferentially postposed, with rates varying between $63 \%$ and $68 \%$ from the $18^{\text {th }}$ century on.

Finally, let us consider Graph 03 that shows the compared evolution of preposed (against postposed) arguments considering the average rates along the centuries in the three kinds of constructions. 


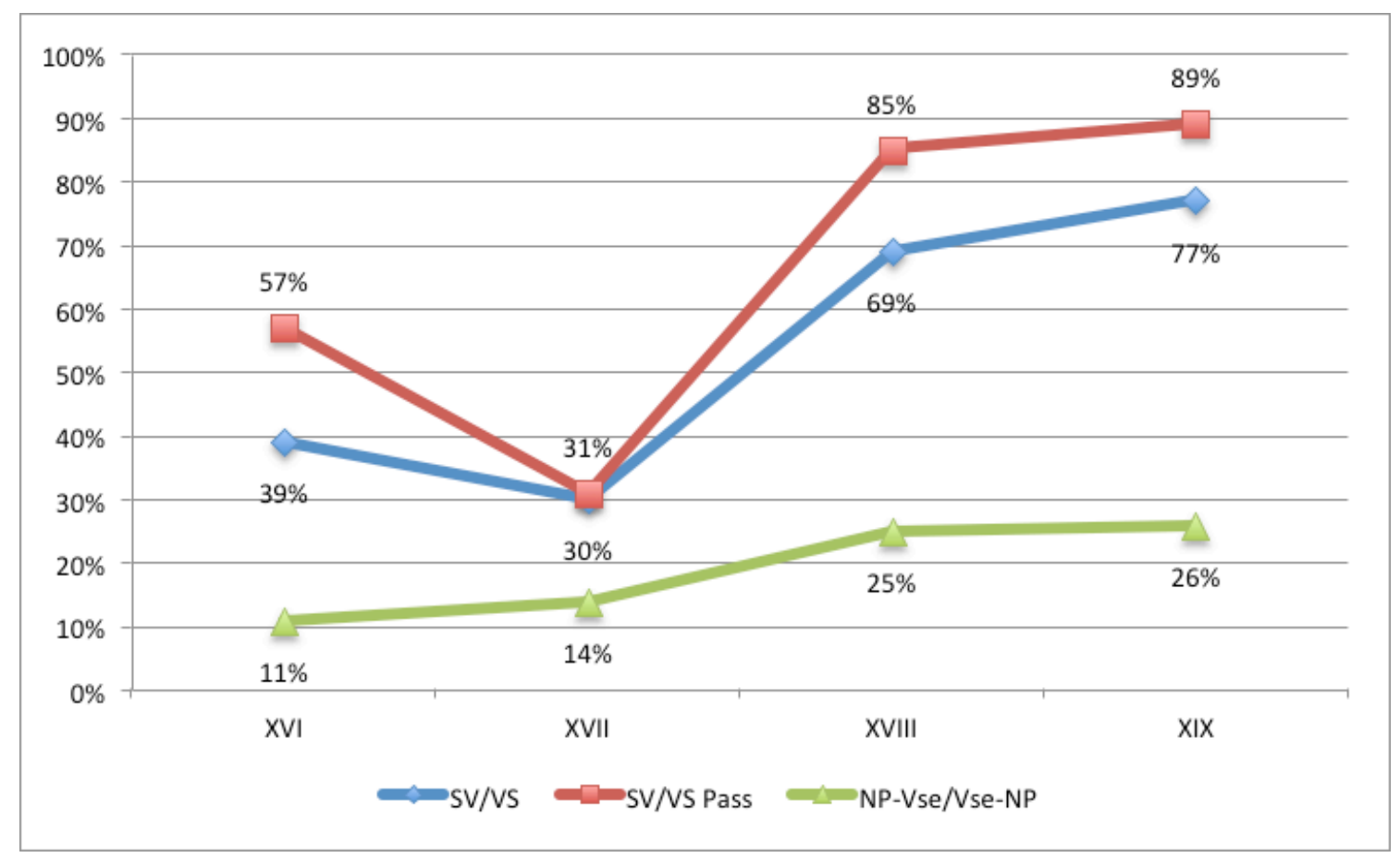

Graph 03. Compared evolution of preposed arguments in active, passive and SE-constructions by century.

When we see the compared evolution of preposed against postposed arguments, the rate of preposed subjects (in active and passive constructions) is sharpened from the $18^{\text {th }}$ century on, whereas the rate of preposed arguments in SE-constructions remain stable, showing only a slight increase. Graphs 02 and 03, taken together, show that active and passive clauses flash the different grammatical character of the subject in consequence of the loss of V2, while SE-constructions seem not to be affected by the change.

These rates may be explained on the lines of Raposo and Uriagereka's (1996) proposal. Differently from other approaches for SE-constructions in Romance (specially in the GB framework), Raposo and Uriagereka propose that SE goes to the subject position (Spec, T) and the preposed DP goes to a higher position, namely [Spec, F], to where topic prominent constituents move. This approach accounts for the contrast seen in (09a) and (09b), brought by the authors:

(09) a. Os especialistas consultaram-se durante a operação The specialists consult-PST.3PL=SE during the surgery.

"The specialists consulted one another during the surgery" AND/OR "They were consulted"

b. Em que momento da operação os especialistas se consultaram? In which moment of the surgery the specialists SE=consult-PST.3PL.

"In wich moment of the surgery have the specialists consulted one another?" (ONLY)

Raposo and Uriagereka (1996) claim that (09a) is ambiguous between a reciprocal and an indefinite reading, whereas (09b) has only a reciprocal reading. This contrast is explained because in (09b) the wh-phrase "em que momento da operação" moves to [Spec, F] and the only available position for the DP "os especialistas" is the subject position. Therefore, in Portuguese, the passive-indefinite reading is possible only when the preposed DP is in this topic position.

If we relate this analysis to the observed pattern in Graph 02, we see that the rate of topicalization (fronting) of DPs in SE-constructions remains stable along the time, because this kind of movement is due to discursive constraints, such as prominence, contrastive topic, etc. The frequency of this kind of topicalization is not expected to rise along the time. In fact, both CIP and EP grammars allow discourse driven constituent fronting. Subject preposing, on the other hand, becomes in the SV grammar, a grammatical requirement, which explains the sharp raise in subject preposing from the $18^{\text {th }}$ century on.

Finally, we should state that the higher rates of argument preposing in SE-constructions appear in two specific authors: Antonio Vieira, born in 1608 and Matias Aires, born in 1702 . Vieira shows a rate of $23 \%$ of preposed 
DPs, while the $17^{\text {th }}$ century average is $14 \%$; Aires presents $50 \%$ of preposed DPs in these constructions, while the $18^{\text {th }}$ century average is $25 \%$. One plausible explanation for these peaks in frequency is related to the nature of the texts: both Vieira and Aires make an intense use of contrastive topics. Galves (2002) has shown that this stylistic artifice is responsible for the elevated frequency of enclisis in Vieira's Sermons, which is divergent from the rate of enclisis in Vieira's Letters (see GALVES; BRITTO; PAIXÃO DE SOUSA, 2005). Examples in (10) and (11) show this contrast:

(10) O terceiro Advento é particular e invisível, no qual vem o mesmo Christo julgar na hora da morte a cada um de nós, e este Juiso se faz no instante em que a alma se aparta do corpo.

(11) a. por isso as mercês de um Rei mostram a sua inclinação, e não a sua intenção: as graças deos Reis, e as de Deus, só se pagam com amor. (Aires, b. 1705)

b. No exercício do mal achamos uma espécie de doçura, e de naturalidade, as virtudes praticam-se por ensino: o vício sabe-se, a virtude aprende-se.

These findings shed a new light onto the syntax of SE-constructions. Such constructions are not affected by the change that affected regular subjects, because they do not involve post-verbal or pre-verbal subjects at all - be it in Classical or in Modern European Portuguese. In either grammar, SE-constructions with preposed arguments should be considered as constructions with fronted complements; and, as opposed to other constructions that in fact involve subjects, Se-constructions do not present a steep elevation in frequency as the SV grammar is established in the texts.

The difference between Classical and Modern SE-constructions with preposed arguments is that in Classical Portuguese, they are fronting constructions within a V2 grammar (just like the fronted subjects and complements of other constructions), whereas in Modern European Portuguese they are topicalizations in a SV grammar, as Raposo and Uriagereka (1996) propose.

\section{Final Remarks}

Two main conclusions are drawn from this paper: first, the change in the syntax of subjects in Portuguese after the 18th century happens regardless of the status of the subjects as external or internal arguments. Second, this change does not affect non-subjects. This has important consequences for the understanding of the change from 16th-17th century Portuguese to Modern European Portuguese and for the understanding of the syntax of subjects in Modern European Portuguese. As regards the diachronic aspects, our work consolidates the analyses of Galves et al. (2005), Galves and Paixão de Sousa $(2005 ; 2015)$ and Paixão de Sousa (2004) to the effect that the change from $16^{\text {th }}-17^{\text {th }}$ century Portuguese to Modern European Portuguese is fundamentally a change in subject position.

More specifically, the change consists in the upsurge of a grammar in which there is a preverbal position exclusive for subjects. As regards Modern European Portuguese, this impacts two much-debated issues in recent literature: first, it provides statistical support to the analyses according to which pre-verbal subjects in EP do not occupy a clause-external topic position, as argued by Pilar Barbosa in many papers (cf. a.o. BARBOSA, 2000) but rather, a clause-internal subject position (COSTA; GALVES, 2002; COSTA; DUARTE, 2003; GALVES; SANDALO, 2012). Second, it provides further evidence to the analyses according to which the internal arguments of SEconstructions do not occupy the subject position, but rather, a topic position (RAPOSO; URIAGEREKA, 1996). In conclusion, our paper reveals the crucial role of the diachronic relation between topics and subjects in the grammatical change that originated Modern European Portuguese, and proposes that the dynamics of this change may elucidate important discussions on the syntax of the current language.

\section{References}

AMBAR, M. Para uma sintaxe da inversão Verbo-Sujeito em português. Lisboa: Colibri, 1992.

BARBOSA, P. Clitics: a window into the null subject properties. In: COSTA, J. (Ed.). Portuguese Syntax - New Comparative Studies. Oxford: Oxford University Press, 2000. p. 31-93. 
CAVALCANTE, S. R.; PAIXÃO DE SOUSA, M. C. Subject position and SE-constructions in the history of Portuguese. Paper Presented at Going Romance, 23, Nice/Nijmegen, December 2009.

.; GALVES, C. M. C.; PAIXÃO DE SOUSA, M. C. Topics, Subjects and Grammatical Change: From Classical to Modern European Portuguese. Paper presented at Subjects in Diachrony: Grammatical Change and the Expression of Subjects. Regensburg Universität, Regensburg, November 2010.

CINQUE, G. On si constructions and the theory of arb. Linguistic Inquiry, 19, p. 521-581, 1988.

COSTA, J. Subject positions and interfaces: the case of European Portuguese. Berlin: Mouton de Gruyter, 2004.

; GALVES, C. External subjects in two varieties of Portuguese. In: BEYSSADE, C; BOK-BENNEMA, R.; DRIJKONINGEN, F.; MONACHESI, P. (Eds.). Romance Languages and Linguistic Theory 2000. Amsterdam / Philadelphia: John Benjamins, 2002. p. 109-125.

.; DUARTE, I. Preverbal subjects in null subject languages are not necessarily dislocated. Journal of Portuguese Linguistics, p. 159-176, 2003.

CRUSCHINA, S; SITARIDOU, I. From Modern to Old Romance: The Interaction between Information Structure and Word Order. Paper presented at DICS 11, University of Campinas, July 22-24, 2009.

CYRINO, S. Construções com se e promoção de argumento no português brasileiro: uma investigação diacrônica. Revista da ABRALIN, 6, p. 85-116, 2007.

DOBROVIE-SORIN, C. Impersonal se Constructions in Romance and the passivization of unergatives. Linguistic Inquiry, 29, p. 399-437, 1998.

GALVES, C. Clitic-Placement and Parametric Change in Portuguese. In: SALTARELLI, M. (Ed.). Aspects of Romance Linguistics, Selected papers from the 24th LSRL. Georgetown University Press, 1996. p. 227-240.

. Syntax and Style: clitic-placement in Padre Antonio Vieira. Santa Barbara Portuguese Studies, 6, p. 387-403, 2002.

; BRITTO, H.; PAIXÃO DE SOUSA, M. C. The change in clitic placement from Classical to Modern European Portuguese: results from the Tycho Brahe Corpus. Journal of Portuguese Linguistics, 4, p. 39-68, 2005.

.; FARIA, P. The Tycho Brahe Parsed Corpus of Historical Portuguese. 2010. <http://www.tycho.iel.unicamp.br>.

.; GIBRAIL, A. Subject inversion in transitive sentences from Classical to Modern European Portuguese: a

corpus-based study. In: CARDOSO, A.; MARTINS, A. M. (Eds.). Word Order Change. Oxford: Oxford University Press, 2016.

.; PAIXÃO DE SOUSA, M. C. The loss of V-to-C in the history of Portuguese: subject position, clitic placement and prosody. Paper submitted to Journal of Historical Syntax, 2015.

; SANDALO, F. From Intonational Phrase to Syntactic Phase: the grammaticalization of enclisis in the history of Portuguese. Lingua, 122, 8, p. 952-974, 2012.

GIBRAIL, A. V. B. Contexto de formação de estruturas de tópico, foco e adjuntos prepostos no português clássico. Ph.D. Dissertation. University of Campinas, 2010.

MANZINI, M. R. 1986. On italian si. Syntax and semantics: the syntax of pronominal. Florida: Academic Press, 1986.

NARO, A. The genesis of reflexive impersonal in Portuguese. Language, 52, p. 779-810, 1976.

PAIXÃO DE SOUSA, M. C. Língua barroca: Sintaxe e história do português nos 1600. Ph.D. dissertation, University of Campinas, 2004.

RAPOSO, E.; URIAGEREKA, J. Indefinite SE. Natural Language and Linguistic Theory, p. 749-810, 1996.

RIBEIRO, I. A sintaxe da ordem no português arcaico; o efeito V2. Ph.D. dissertation, University of Campinas, 1995.

TORRES MORAES, M. A. Do Português Clássico Ao Português Europeu Moderno, Um Estudo Diacrônico da Cliticização e do Movimento do Verbo. Ph.D. dissertation, University of Campinas, 1995. 